Original article

\title{
Alcohol and tobacco influencing prevalence of hypertension among 15-54 years old Indian men: An application of discriminant analysis using National Family Health Survey (NFHS), 2015-16
}

\author{
Jeetendra Yadav $^{\mathrm{a},{ }^{*}, \text { Shaziya Allarakha }}{ }^{\mathrm{b}}$, Chander Shekhar ${ }^{\mathrm{c}}$, Ganesh Prasad Jena ${ }^{\mathrm{a}}$ \\ ${ }^{\text {a }}$ ICMR-National Institute of Medical Statistics, Ansari Nagar, New Delhi, 110029, India \\ ${ }^{\mathrm{b}}$ Medical Consultant WebMD Health Services, LLC, New Delhi, India \\ ${ }^{\mathrm{c}}$ Department of Fertility Studies, International Institute for Population Sciences (IIPS), Govandi Station Road, Deonar, Opposite Sanjona Chamber, Mumbai, \\ Maharashtra, 400088, India
}

\section{A R T I C L E I N F O}

\section{Keywords:}

Hypertension

Risk factors

Alcohol. tobacco and discriminant analysis

\begin{abstract}
A B S T R A C T
Background: Hypertension has been described as an "iceberg disease" as those who suffer are usually unaware and hence usually seek healthcare services at a very late stage. It is estimated that more than two million Indians are suffering from hypertensive heart diseases that contributed to above 0.13 million deaths in 2016 .

Objectives: The present study aims to know the prevalence of Hypertension in India and its variation by socioeconomic backgrounds, and to find out risk factors discriminating hypertension with special emphasis on tobacco and alcohol consumption among men aged 15-54 years in India.

Methods: In this study, NFHS (2015-16) data were analyzed by applying binary logistic regression and discriminant analysis in the attempt to find significant predictors and discriminants of interest.

Results: The prevalence of hypertension was $16.5 \%$ in the study population. The results suggested that the consumption of alcohol and tobacco are significant discriminant characteristics associated with hypertension irrespective of the socioeconomic background characteristics of the respondents. Hypertension is a chronic disease and is itself a causative factor for several other diseases like renal impairment, other cardiovascular diseases, and stroke.

Conclusions: The findings are expected to have direct implications on public health interventions and policy formulation to reduce diseases caused by tobacco and alcohol, particularly hypertension among men in the potential economically productive age group in India and similar settings.
\end{abstract}

What is already known?

$>$ More than 2 million Indians are suffering from hypertensive heart disease that contributed to above 0.13 million deaths in 2016.

$>$ Substance use is an important predictor of hypertension irrespective of socioeconomic background characteristics.

$>$ Alcohol and tobacco consumption, both smoking as well as smokeless, are linked to elevated blood pressure and other cardiovascular diseases in both men and women
What does this study add?

$>$ This is the first time in the history of NFHS in India that such a critical association on a large-scale population-based nationally representative survey has been made.

$>$ The finding has direct implications on framing policies for reducing diseases caused by tobacco and alcohol.

$>$ The lowest share of normotensive people belonged to the age group 40-49

$>$ Consumption of alcohol and tobacco alone, or together, was found to be a very crucial determinant of elevation in BP

\footnotetext{
* Corresponding author. ICMR-National Institute of Medical Statistics, India.

E-mail addresses: jeetu.nims@gmail.com (J. Yadav), doctorshaziya@gmail.com (S. Allarakha), buddhab@iips.net (C. Shekhar), ganeshp_jena@yahoo.co.in (G.P. Jena).
} 


\section{Introduction}

Hypertension is defined as a chronic elevation in blood pressure (BP): systolic $\geq 130 \mathrm{mmHg}$ or diastolic $\geq 80 \mathrm{~mm} \mathrm{Hg}^{1,2} \mathrm{BP}$ in the range of $130-139 \mathrm{~mm} \mathrm{Hg}$ systolic or $80-89 \mathrm{~mm} \mathrm{Hg}$ diastolic is termed as hypertension (previously referred to as Pre-hypertension), while stage 2 hypertension refers to BP $140 / 90 \mathrm{~mm} \mathrm{Hg}$ or higher. ${ }^{3}$ Being the commonest cardiovascular disorder, hypertension is a crucial public health problem as it is associated with stroke, coronary heart diseases, and other vascular complications. ${ }^{1}$ Hypertension is present in $69 \%$ of the cases with a first myocardial infarction (MI), $77 \%$ of the patients with a first stroke, $74 \%$ of the cases of chronic heart failure, and $60 \%$ of the patients with peripheral artery diseases. ${ }^{2}$ It is interesting to note that in the majority (80-95\%) of the cases the etiology of hypertension is unknown, such cases are termed as patients of primary or "essential" hypertension, and cases where BP is raised due to some underlying pathology/drugs, fall into the category of secondary hypertension. ${ }^{3}$ Secondary hypertension can occur due to a variety of reasons like renal parenchymal diseases, renal artery stenosis (termed as renovascular hypertension), drugs (Oral Contraceptive Pills (OCPs), cocaine, steroids, etc.), pheochromocytoma, coarctation of aorta, aldosterone secreting tumors, etc. ${ }^{4-6}$ These causes should be ruled out before initiating therapy for raised BP.

Hypertension has been aptly described as an "iceberg disease" as its sufferers are rarely aware of it, and hence, usually seek healthcare services very late. ${ }^{7}$ Perhaps, this inertia in seeking healthcare is one of the reasons behind changing the previous classification of pre-hypertension to stage 1 disease. According to a recently published study, the trend of hypertension in India differs from that in developed countries where the burden is mainly in the socioeconomically weaker groups, while in India, there is no particular pattern. ${ }^{8}$ However, the burden of deaths due to hypertensive disorders is concentrated among the lower socioeconomic strata of the society. ${ }^{9}$ A study done in Thailand revealed that heavy alcohol consumption is associated with a higher risk of hypertension and other Non-Communicable Diseases (NCDs). ${ }^{10}$ Furthermore, genetic defects associated with alcohol metabolizing genes further contribute to the development of hypertension. ${ }^{11}$ Although some studies have suggested that there might be a protective effect of hormones in females against the hypertensive effect of alcohol, but, a recent meta-analysis suggests that there is no such protective effect and both the genders are equally susceptible to the hypertensive effects of alcohol. $^{12,13}$

Several studies have stated that tobacco consumption, both smoking as well as smokeless, is linked to elevated blood pressure and other cardiovascular diseases in both men and women. ${ }^{14-16}$ Tobacco has multiple reasons for causing raised blood pressure, these include endothelial dysfunction, raised cardiac output, and peripheral vascular resistance. Furthermore, as tobacco blunts the BP-lowering effect of beta-blockers, the treatment of hypertension in tobacco users also becomes tricky. ${ }^{15-17}$ Many risk factors are associated with hypertension. These include age, body mass index, gender, diet, physical activity, socioeconomic status, emotional stress, and drugs., ${ }^{9,19}$ Age is an important contributor as found in many studies; one study has revealed that hypertension is significantly higher in the age group ' 35 years and above' as compared to the age group ' $0-35$ years'. ${ }^{18,20}$ Furthermore, higher age makes management of hypertension more difficult and increasing associated with the development of complications in the patients. ${ }^{19}$ There is a significant difference amongst different education classes as well, with more educated people being less prone to develop hypertension. ${ }^{18}$

Based on the above background of the study, this study analyses the prevalence of hypertension by socio-economic backgrounds and attempts to find risk factors of hypertension in India. The authors believe that this will provide clues for further strengthening the health care policies for curbing substance abuse and hypertension in India. It will be the first study, which will be based on a nationally representative large- scale sample survey in India.

\section{Methods}

\subsection{Data source}

This study uses data from the fourth round of the National Family Health Survey (NFHS)-4, the Indian version of the Demographic and Health Survey (DHS), conducted in the year 2015-16. NFHS-4 is the first nationwide community-based survey in India to provide estimates of blood pressure and blood glucose levels in the general population. BP was measured for eligible women aged 15-49 and (in the state module subsample of households only) eligible men aged 15-54, using an Omron BP Monitor to determine the prevalence of hypertension. BP measurements for each respondent were taken three times with an interval of 5 min between two consecutive readings.

\subsection{Sampling techniques and study population}

The NFHS- 4 sample is a stratified two-stage sample. The 2011 census served as the sampling frame for the selection of primary sampling units (PSUs). PSUs were villages in rural areas and Census Enumeration Blocks (CEBs) in urban areas. PSUs with fewer than 40 households were linked to the nearest PSU. For this study analysis considered 1,12,122 males aged 15-54 from 1778 clusters (PSUs) in 640 districts of India. $^{8}$

\subsection{Outcome measurements}

The outcome variable for this study was hypertension. An individual is classified as having hypertension if the systolic blood pressure level is greater than or equal to $140 \mathrm{mmHg}$, or diastolic blood pressure is greater than or equal to $90 \mathrm{mmHg}$, or s/he is currently taking antihypertensive medication(s) to lower her/his blood pressure. In the NFHS-4, blood pressure (both diastolic and systolic) of respondents was measured three times following a 5-min gap for the second and third reading. This study has considered the average of the last two readings as suggested in the literature that it help in avoiding upward bias due to anxiety or nervousness while taking the very first reading.

\subsection{Defining predictor variables}

Based on the theoretical and observed importance applied in the literature and available in the NFHS data-set, significant socioeconomic and risk factors considered in this study are age, education, marital status, occupation, religion, caste/tribe, economic status (wealth index, i.e., wealth quintiles), place of residence, tobacco alcohol, dietary habits and body mass index (BMI). ${ }^{9,18,21,22}$

The NFHS-4 canvassed following questions on tobacco and alcohol consumption to the respondents. There were respectively (a) Do you currently smoke or use tobacco in any other form? (b) Do you drink alcohol? The response of each question were sought in dichotomous form as "Yes" and "No". In this paper, a respondent is considered as consumer of tobacco if he answered to the question (a) in "Yes". He is considered as consumer of alcohol if answered to the question (b) in "Yes". The survey asked tobacco consumed in any form (like raw or various local means) as well as through smoking. However, no passive or second hand smoking is considered in the definition. Alcohol is also available in various form including locally made liquor and branded ones. No minimum limit on the quantity of alcohol was considered in the definition. These are limitations of data in the large-scale survey.

\subsection{Analytical approach}

To meet the objective, this study used univariate logistic regression to identify the associated significant risk factors and then used the Fisher's discriminant analysis to establish a simple and useful prediction 
Table 1

Background characteristics of the sampled study Population.

\begin{tabular}{|c|c|c|}
\hline Background Characteristics & $\begin{array}{l}\text { Weighted } \\
\text { Sample }^{\mathrm{a}}\end{array}$ & $\begin{array}{l}\text { Weighted } \\
\text { proportion }\end{array}$ \\
\hline \multicolumn{3}{|l|}{ Individuals characteristics } \\
\hline $15-24$ & 35,363 & 31.5 \\
\hline $25-40$ & 48,559 & 43.3 \\
\hline $41-49$ & 28,200 & 25.2 \\
\hline \multicolumn{3}{|l|}{ Education } \\
\hline Non-literate & 14,592 & 13.0 \\
\hline Below Primary & 7371 & 6.6 \\
\hline Below Middle & 6720 & 5.9 \\
\hline Below Secondary & 51,240 & 45.7 \\
\hline Secondary and above & 32,200 & 28.7 \\
\hline \multicolumn{3}{|l|}{ Marital Status } \\
\hline Never married & 39,762 & 35.5 \\
\hline Currently married & 70,782 & 63.1 \\
\hline Others & 1578 & 1.4 \\
\hline \multicolumn{3}{|l|}{ Occupation } \\
\hline Not working & 24,818 & 22.1 \\
\hline Agricultural work & 30,202 & 26.9 \\
\hline Skilled/Unskilled work & 28,910 & 25.8 \\
\hline Professional work & 28,191 & 25.1 \\
\hline \multicolumn{3}{|l|}{ Household characteristics } \\
\hline \multicolumn{3}{|l|}{ Religion } \\
\hline Hindu & 91,390 & 81.5 \\
\hline Non-Hindu & 20,732 & 18.5 \\
\hline \multicolumn{3}{|l|}{ Social group } \\
\hline Scheduled Tribe & 9870 & 9.2 \\
\hline Scheduled Caste & 22,138 & 20.6 \\
\hline Other Backward Class & 48,848 & 45.4 \\
\hline Others & 26,673 & 24.8 \\
\hline \multicolumn{3}{|l|}{ Wealth quintile } \\
\hline Poorest & 16,437 & 14.7 \\
\hline Poorer & 20,902 & 18.6 \\
\hline Middle & 23,689 & 21.1 \\
\hline Richer & 24,979 & 22.3 \\
\hline Richest & 26,115 & 23.3 \\
\hline \multicolumn{3}{|l|}{ Community characteristics } \\
\hline \multicolumn{3}{|l|}{ Place of residence } \\
\hline Rural & 42,955 & 38.3 \\
\hline Urban & 69,167 & 61.7 \\
\hline \multicolumn{3}{|l|}{ Region } \\
\hline North & 13,187 & 11.8 \\
\hline Central & 24,931 & 22.2 \\
\hline East & 21,046 & 18.8 \\
\hline Northeast & 3692 & 3.3 \\
\hline West & 20,491 & 18.3 \\
\hline South & 26,602 & 23.7 \\
\hline Union Territories & 2174 & 01.9 \\
\hline Risk behaviour & & \\
\hline Smoking & & \\
\hline No & 61,087 & 54.5 \\
\hline Yes & 51,035 & 45.5 \\
\hline Alcohol & & \\
\hline No & 79,029 & 70.5 \\
\hline Yes & 33,093 & 29.5 \\
\hline Either Tobacco or Alcohol & & \\
\hline No & 51,451 & 45.9 \\
\hline Yes & 60,671 & 54.1 \\
\hline Both Tobacco and Alcohol & & \\
\hline No & 88,665 & 79.1 \\
\hline Yes & 23,457 & 20.9 \\
\hline Diet & & \\
\hline Vegetarian & 32,095 & 28.6 \\
\hline Non-vegetarian & 80,027 & 71.4 \\
\hline Diabetic & & \\
\hline No & $1,09,726$ & 97.9 \\
\hline Yes & 2396 & 02.1 \\
\hline $\begin{array}{l}\text { Told by a doctor that he h } \\
\text { or high blood pressure }\end{array}$ & & \\
\hline No & $1,04,828$ & 97.4 \\
\hline Yes & 2757 & 2.6 \\
\hline BMI & & \\
\hline Low & 21,347 & 19.8 \\
\hline
\end{tabular}

Table 1 (continued)

\begin{tabular}{llll}
\hline Background Characteristics & $\begin{array}{l}\text { Weighted } \\
\text { Sample }^{\mathrm{a}}\end{array}$ & & $\begin{array}{l}\text { Weighted } \\
\text { proportion }\end{array}$ \\
\cline { 1 - 1 } Medium & 65,145 & 60.0 \\
High & 17,600 & 16.4 \\
Obese & 3552 & 03.3 \\
Total & $\mathbf{1 , 1 2 , 1 2 2}$ & $\mathbf{1 0 0}$ \\
\hline
\end{tabular}

Sources: Based on author's computation from NFHS-4 (2015-16).

${ }^{a}$ The total may not be equal due to some missing cases.

model based on the significant predictors. Univariate analysis could not control the confounding effect of other variables or avoid the collinearity among some variables. Thus, in the Fisher discriminant analysis, we used a stepwise method to determine the final prediction, which could control the confounding effect and overcome the collinearity between variables. Fisher's discriminant analysis was done to find a linear combination for categorical groups, as the discriminant scores (Z) were calculated to maximize the between-group variance and minimize the within-group variation.

\section{Results}

\subsection{Background characteristics of the respondents}

Table 1 shows the background characteristics of our study participants. It can be seen that the study population had a higher proportion of young individuals (age group 15-40 years constituted more than $2 / 3 \mathrm{rd}$ of the participants). Of the surveyed population, around $13 \%$ were illiterate individuals, the highest proportion was of the individuals who had been educated below the middle secondary school (45.7\%) followed by the secondary and above (28.7\%). If we consider the marital status, married individuals contributed to the greatest share of participants (63.1\%). Amongst the different occupational groups, the proportion of participants was nearly equal, the lowest proportion amongst them was the not working category participants. The highest proportion of study subjects were from the southern region followed by the central region of the country. Around $55 \%$ of subjects reported as current smokers and around $71 \%$ reported as current consumers of alcohol in the survey while $21 \%$ of all subjects reported consuming both tobacco and alcohol regularly. Most of the participants were non-vegetarians $(71.4 \%)$. Almost 98\% surveyed individuals in this study were non-diabetics.

\subsection{Prevalence of hypertension by sociodemographic characteristics and behavioral risk factors}

Table 2 depicts the prevalence of hypertension according to various sociodemographic characteristics and behavioral risk factors. The upper limit for normotensive individuals was $120 \mathrm{mmHg}$ systolic and 80 $\mathrm{mmHg}$ diastolic blood pressure. Mildly high BP has a cut off value of 140 and $90 \mathrm{mmHg}$ for systolic and diastolic BP respectively. It can be seen that the higher the age of the subject, the greater is the likelihood of being mildly hypertensive. Also, it can be observed that irrespective of the sociodemographic variables, individuals who use either tobacco or alcohol or both had a greater percentage of hypertensives than their counterparts. Nonetheless, the effects of other contributing factors seem to add up to the percentage of hypertensive individuals in the respective group. For example, in younger (15-24 yrs) addicts (of alcohol/tobacco/ both) the percentage of hypertensives is lower than their older counterparts (25-40 yrs and 41-49 yrs). Furthermore, mildly high BP was more prevalent in non-vegetarians than vegetarian subjects. Participants who were diabetic had a higher proportion of mildly high BP than nondiabetics. 
Table 2

Prevalence of hypertension by sociodemographic characteristics and behavioral risk factors.

\begin{tabular}{|c|c|c|c|c|c|}
\hline \multirow[t]{2}{*}{$\begin{array}{l}\text { Individuals } \\
\text { characteristics }\end{array}$} & \multirow{2}{*}{$\begin{array}{l}\text { Tobacco } \\
\%\end{array}$} & \multirow{2}{*}{$\begin{array}{l}\text { Alcohol } \\
\%\end{array}$} & \multirow{2}{*}{$\begin{array}{l}\text { Both } \\
\text { Tobacco and } \\
\text { Alcohol } \\
\%\end{array}$} & \multicolumn{2}{|c|}{$\begin{array}{l}\text { Prevalence of } \\
\text { Hypertension }\end{array}$} \\
\hline & & & & $\%$ & $95 \% \mathrm{CI}$ \\
\hline \multicolumn{6}{|l|}{ Age (in years) } \\
\hline $15-24$ & 27.3 & 16.1 & 10.5 & 5.6 & [05.2-05.9] \\
\hline $25-40$ & 52.3 & 35.9 & 25.6 & 17.2 & [16.6-17.7] \\
\hline $41-49$ & 56.7 & 35.3 & 25.9 & 30.4 & [29.5-31.3] \\
\hline \multicolumn{6}{|l|}{ Education } \\
\hline Non-literate & 68.4 & 40.0 & 33.4 & 18.1 & [17.2-19.0] \\
\hline Below Primary & 67.4 & 36.1 & 29.8 & 20.7 & [19.3-22.3] \\
\hline Below Middle & 62.2 & 36.7 & 29.1 & 17.9 & [16.5-19.3] \\
\hline Below Secondary & 44.1 & 27.9 & 19.7 & 15.5 & [14.9-16.0] \\
\hline $\begin{array}{l}\text { Secondary and } \\
\text { above }\end{array}$ & 28.9 & 24.3 & 13.4 & 17.5 & [16.8-18.2] \\
\hline \multicolumn{6}{|l|}{ Marital Status } \\
\hline Never married & 27.9 & 18.7 & 11.9 & 7.5 & {$[07.1-08.0]$} \\
\hline Currently married & 54.9 & 35.3 & 25.7 & 21.9 & [21.4-22.4] \\
\hline Others & 70 & 39.9 & 35.0 & 21.6 & [18.6-25.0] \\
\hline \multicolumn{6}{|l|}{ Occupation } \\
\hline Not working & 22.3 & 14.5 & 9.1 & 9.1 & [08.6-09.6] \\
\hline Agricultural work & 56.8 & 32.2 & 24.7 & 17.2 & [16.6-17.8] \\
\hline $\begin{array}{l}\text { Skilled/Unskilled } \\
\text { work }\end{array}$ & 58.4 & 37.9 & 28.5 & 17.9 & [17.2-18.7] \\
\hline Professional work & 40.6 & 31.2 & 19.5 & 22.3 & [21.4-23.3] \\
\hline \multicolumn{6}{|l|}{$\begin{array}{l}\text { Household } \\
\text { characteristics }\end{array}$} \\
\hline \multicolumn{6}{|l|}{ Religion } \\
\hline Hindu & 46.1 & 31.9 & 22.9 & 16.9 & [16.5-17.3] \\
\hline Non-Hindu & 43.0 & 19.1 & 12.3 & 16.7 & [15.9-17.6] \\
\hline \multicolumn{6}{|l|}{ Social group } \\
\hline Scheduled Tribe & 57.7 & 41.9 & 33.4 & 16.6 & [15.7-17.5] \\
\hline Scheduled Caste & 50.0 & 36.9 & 27.9 & 16.6 & [15.8-17.4] \\
\hline $\begin{array}{l}\text { Other Backward } \\
\text { Class }\end{array}$ & 43.5 & 28.9 & 19.5 & 16.4 & [15.9-17.0] \\
\hline Others & 40.9 & 21.8 & 14.4 & 18.2 & [17.4-19.1] \\
\hline \multicolumn{6}{|l|}{ Wealth quintile } \\
\hline Poorest & 64.2 & 35.8 & 31.5 & 12.2 & [11.6-12.8] \\
\hline Poorer & 55.9 & 30.2 & 24.5 & 13.2 & [12.6-13.9] \\
\hline Middle & 46.6 & 30.3 & 21.3 & 16.6 & [15.9-17.4] \\
\hline Richer & 39.7 & 28.4 & 17.7 & 19.7 & [18.9-20.6] \\
\hline Richest & 30.0 & 25.3 & 14.1 & 20.4 & [19.5-21.4] \\
\hline \multicolumn{6}{|l|}{$\begin{array}{l}\text { Community } \\
\text { characteristics }\end{array}$} \\
\hline $\begin{array}{l}\text { Place of } \\
\text { residence }\end{array}$ & & & & & \\
\hline Urban & 39.7 & 29.1 & 19.1 & 18.9 & [18.1-19.7] \\
\hline Rural & 49.2 & 29.8 & 22.1 & 15.7 & [15.3-16.1] \\
\hline Region & & & & & \\
\hline North & 38.7 & 22.6 & 13.9 & 19.2 & [18.4-20.0] \\
\hline Central & 55.8 & 27.9 & 23.6 & 13.6 & [13.1-14.1] \\
\hline East & 55.5 & 31.7 & 26.9 & 14.6 & [13.9-15.5] \\
\hline Northeast & 65.8 & 40.7 & 33.9 & 23.2 & [22.1-24.4] \\
\hline West & 43.7 & 17.0 & 12.1 & 18.1 & [16.8-19.4] \\
\hline South & 31.2 & 41.0 & 22.3 & 19.4 & [18.5-20.3] \\
\hline Union Territories & 30.3 & 27.6 & 18.5 & 9.7 & [07.7-12.2] \\
\hline Risk factors & & & & & \\
\hline Tobacco & & & & & \\
\hline No & - & 15.8 & - & 15.4 & [14.9-15.9] \\
\hline Yes & - & 46.0 & - & 18.6 & [18.1-19.1] \\
\hline Alcohol & & & & & \\
\hline No & 34.9 & - & - & 14.9 & [14.4-15.3] \\
\hline Yes & 70.9 & - & - & 21.6 & [20.9-22.4] \\
\hline $\begin{array}{l}\text { Either Tobacco or } \\
\text { Alcohol }\end{array}$ & & & & & \\
\hline No & - & - & - & 14.1 & [13.5-14.6] \\
\hline Yes & - & - & - & 19.2 & [18.7-19.7] \\
\hline $\begin{array}{l}\text { Both Tobacco } \\
\text { and Alcohol }\end{array}$ & & & & & \\
\hline No & - & - & - & 15.7 & [15.3-16.1] \\
\hline Yes & - & - & - & 21.3 & [20.5-22.1] \\
\hline Diet & & & & & \\
\hline Vegetarian & 40.6 & 15.3 & 10.4 & 15.7 & [15.1-16.3] \\
\hline Non-vegetarian & 47.5 & 35.2 & 25.1 & 17.4 & [16.9-17.8] \\
\hline
\end{tabular}

Table 2 (continued)

\begin{tabular}{|c|c|c|c|c|c|}
\hline \multirow[t]{2}{*}{$\begin{array}{l}\text { Individuals } \\
\text { characteristics }\end{array}$} & \multirow{2}{*}{$\begin{array}{l}\text { Tobacco } \\
\%\end{array}$} & \multirow{2}{*}{$\begin{array}{l}\text { Alcohol } \\
\%\end{array}$} & \multirow{2}{*}{$\begin{array}{l}\text { Both } \\
\text { Tobacco and } \\
\text { Alcohol } \\
\%\end{array}$} & \multicolumn{2}{|c|}{$\begin{array}{l}\text { Prevalence of } \\
\text { Hypertension }\end{array}$} \\
\hline & & & & $\%$ & $95 \%$ CI \\
\hline \multicolumn{6}{|l|}{ Diabetic } \\
\hline No & 45.5 & 29.3 & 20.8 & 16.4 & [16.0-16.8] \\
\hline Yes & 46.9 & 39.2 & 26.3 & 38.9 & [35.4-42.4] \\
\hline \multicolumn{6}{|l|}{ BMI } \\
\hline Low & 44.7 & 23.4 & 18.7 & 07.2 & [06.7-07.7] \\
\hline Medium & 48.3 & 31.1 & 22.6 & 15.0 & [14.5-15.5] \\
\hline High & 40.3 & 32.8 & 19.6 & 30.8 & [37.1-42.9] \\
\hline Obese & 36.7 & 28.7 & 16.1 & 40.0 & [16.5-17.2] \\
\hline India & 45.5 & 29.5 & 20.9 & 16.5 & [16.5-17.3] \\
\hline
\end{tabular}

Sources: Based on author's computation from NFHS-4 (2015-16).

\subsection{Prevalence of hypertension according to substance use and socioeconomic characteristics}

In Table 3, it can be seen that irrespective of the age group, individuals who use both alcohol and tobacco have a greater prevalence of hypertension compared to those who neither smoke nor drink alcohol. If we take educational status under consideration, smoking and alcohol, alone or combined, increase the risk of being hypertensive among the various educational groups. However, one paradoxical finding was a relatively higher prevalence of hypertension amongst the currently married non-smokers as compared to smokers. Furthermore, our study reveals that irrespective of wealth quintile, place or region of residence and dietary preferences, alcohol, and smoking lead to greater chances of being hypertensive. It is to be noted that the proportion of hypertensive participants amongst diabetic alcoholic/smokers was higher than nondiabetic alcoholics/smokers, as diabetes itself may lead to cardiovascular morbidity. Similarly, obese individuals tend to have higher chances of getting hypertension irrespective of addiction status as obesity is a major contributor to raised blood pressure besides other cardiovascular abnormalities.

\subsection{Tests of equality of group means}

Table 4 provides strong statistical evidence of significant differences between means of smoker and non-smoker groups for all independent variables with producing a very high value of F's for age, body mass index, marital status, occupation, diabetes, wealth index, use of alcohol, and tobacco. The associations for all the groups within a background characteristic except religion were significantly different.

\subsection{Summary of canonical discriminant functions}

Canonical correlation can tell what proportion of the total variation is due to variation in a discriminant function if we squared it (Table 5). It means around $10 \%$ variation in men carrying hypertension could be explained alone by substance use considered in this study.

\subsection{The standardized canonical discriminant function coefficients}

The interpretation of the discriminant coefficients (or weights) is similar to multiple regression. Table 6 provides an index of the importance of each predictor like the standardized regression coefficients (Beta) dose in multiple regression. The sign indicates the direction of the relationship. Age and BMI were the strongest predictors while marital status and caste (note -ve sign) were next in importance as predictors. Place of residence, wealth quintile, education, and occupation were not as strong predictors as age and BMI. Alcohol alone and both alcohol and smoking together have their independent effects on the person being hypertensive. 
Table 3

Prevalence of hypertension according to substance use and sociodemographic characteristics.

\begin{tabular}{|c|c|c|c|c|c|c|}
\hline \multirow[t]{2}{*}{ Background Characteristics } & \multirow{2}{*}{$\frac{\text { Smoking }}{\text { Hypertension } \%}$} & \multirow{2}{*}{$\frac{\text { Never Smoking }}{\text { Hypertension } \%}$} & \multirow{2}{*}{$\frac{\text { Alcohol }}{\text { Hypertension \% }}$} & \multirow{2}{*}{$\frac{\text { No Alcohol }}{\text { Hypertension } \%}$} & \multirow{2}{*}{$\frac{\text { Both Smoking and Alcohol }}{\text { Hypertension \% }}$} & \multirow{2}{*}{$\frac{\text { Neither of them }}{\text { Hypertension \% }}$} \\
\hline & & & & & & \\
\hline \multicolumn{7}{|l|}{ Individuals characteristics } \\
\hline \multicolumn{7}{|l|}{ Age (in years) } \\
\hline $15-24$ & 6.2 & 5.3 & 7.1 & 5.3 & 7.2 & 5.4 \\
\hline $25-40$ & 17.1 & 17.3 & 19.6 & 15.8 & 19.2 & 16.4 \\
\hline $41-49$ & 28.5 & 32.9 & 33.5 & 28.7 & 32.0 & 29.9 \\
\hline \multicolumn{7}{|l|}{ Education } \\
\hline Non-literate & 18.8 & 16.4 & 22.4 & 15.2 & 22.1 & 16.1 \\
\hline Below Primary & 19.9 & 22.5 & 25.3 & 18.1 & 23.2 & 19.7 \\
\hline Below Middle & 17.7 & 18.1 & 20.3 & 16.5 & 19.3 & 17.3 \\
\hline Below Secondary & 17.7 & 13.6 & 21.3 & 13.2 & 20.6 & 14.2 \\
\hline Secondary and above & 20.3 & 16.3 & 20.9 & 16.4 & 21.9 & 16.8 \\
\hline \multicolumn{7}{|l|}{ Marital Status } \\
\hline Never married & 9.2 & 6.9 & 10.3 & 6.9 & 11.2 & 7.0 \\
\hline Currently married & 21.2 & 22.9 & 24.8 & 20.4 & 23.7 & 21.3 \\
\hline Others & 21.6 & 21.6 & 28 & 17.4 & 27.3 & 18.6 \\
\hline \multicolumn{7}{|l|}{ Occupation } \\
\hline Not working & 14.3 & 7.5 & 15.0 & 8.1 & 16.0 & 8.4 \\
\hline Agricultural work & 17.4 & 17 & 21.2 & 15.3 & 20.7 & 16.1 \\
\hline Skilled/Unskilled work & 18.2 & 17.4 & 21.7 & 15.6 & 21.2 & 16.6 \\
\hline Professional work & 23.1 & 21.8 & 24.8 & 21.2 & 24.6 & 21.8 \\
\hline \multicolumn{7}{|l|}{ Religion } \\
\hline Hindu & 18.8 & 15.3 & 21.4 & 14.8 & 21.1 & 15.6 \\
\hline Non-Hindu & 17.8 & 15.9 & 23.7 & 15 & 22.7 & 15.9 \\
\hline \multicolumn{7}{|l|}{ Social group } \\
\hline ST & 18.9 & 13.4 & 20.7 & 13.6 & 21.1 & 14.3 \\
\hline SC & 18.1 & 15.1 & 21.5 & 13.7 & 20.5 & 15.1 \\
\hline ОВС & 18.3 & 15 & 20.8 & 14.6 & 20.8 & 15.4 \\
\hline Others & 20 & 17 & 24.6 & 16.4 & 24.2 & 17.2 \\
\hline \multicolumn{7}{|l|}{ Wealth quintile } \\
\hline Poorest & 14.4 & 8.1 & 16.2 & 9.9 & 16.6 & 10.1 \\
\hline Poorer & 15.3 & 10.6 & 17.6 & 11.4 & 17.9 & 11.7 \\
\hline Middle & 19.3 & 14.2 & 22.4 & 14.1 & 23.4 & 14.8 \\
\hline Richer & 22.5 & 17.9 & 25.6 & 17.4 & 25.2 & 18.6 \\
\hline Richest & 23.6 & 19 & 25.5 & 18.7 & 25.2 & 19.6 \\
\hline \multicolumn{7}{|l|}{ Place of residence } \\
\hline Urban & 21.4 & 17.2 & 23.4 & 17.0 & 23.4 & 17.8 \\
\hline Rural & 17.3 & 14.2 & 20.6 & 13.6 & 20.2 & 14.4 \\
\hline Region & & & & & & \\
\hline North & 20.7 & 18.2 & 27.8 & 16.7 & 26.6 & 18.0 \\
\hline Central & 14.9 & 11.9 & 17.1 & 12.2 & 17.1 & 12.5 \\
\hline East & 17.1 & 11.6 & 18.9 & 12.7 & 19.2 & 13.0 \\
\hline Northeast & 24.4 & 20.9 & 27.8 & 20 & 27.8 & 20.8 \\
\hline West & 20.6 & 16.1 & 25.8 & 16.4 & 25.3 & 17.0 \\
\hline South & 22.5 & 17.9 & 22.8 & 17.0 & 23.4 & 18.2 \\
\hline Union Territories & 13.1 & 8.0 & 13.2 & 8.2 & 12.7 & 8.9 \\
\hline Diet & & & & & & \\
\hline Vegetarian & 17.5 & 14.4 & 21.3 & 14.7 & 20.9 & 15.1 \\
\hline Non-vegetarian & 19.0 & 15.8 & 21.7 & 15.0 & 21.4 & 16.0 \\
\hline Diabetic & & & & & & \\
\hline No & 18.1 & 14.9 & 21.1 & 14.4 & 20.8 & 15.2 \\
\hline Yes & 41.7 & 36.4 & 42.0 & 36.8 & 38.6 & 38.9 \\
\hline BMI & & & & & & \\
\hline Low & 10.1 & 4.8 & 13.0 & 5.4 & 13.6 & 5.7 \\
\hline Medium & 16.9 & 13.2 & 18.7 & 13.4 & 19.2 & 13.7 \\
\hline High & 33.2 & 29.2 & 35.0 & 28.8 & 35.3 & 29.7 \\
\hline Obese & 41.2 & 39.3 & 46.9 & 37.2 & 42.8 & 39.5 \\
\hline India & 18.6 & 15.4 & 21.6 & 14.9 & 21.3 & 15.7 \\
\hline
\end{tabular}

Sources: Based on author's computation from NFHS-4 (2015-16).

\subsection{Classification of results}

The classification of results in Table 7 reveals that $83.1 \%$ of respondents were classified correctly into 'suffering from hypertension' or 'not suffering from hypertension' groups. It is also called a hit ratio. The ratio beyond $75 \%$ suggests that a variable chosen in discriminant function has a strong power in segregating persons suffering from hypertension, and otherwise. The histogram is given in Fig. 1, drawn from discriminant scores, which depicts the shape of the normal distribution, it again supports whether the variable chosen in the analysis has strong predicting power to a person being hypertensive or not.

\section{Discussion}

The results of the study suggest that substance use is an important predictor of a person being hypertensive, irrespective of what socioeconomic background characteristic s/he possesses. The first time in the history of NFHS in India, this study brings out such a critical association using a large-scale population-based nationally representative survey data. The findings have direct implications for the government's efforts in framing and rolling out policies on preventing diseases caused by tobacco and alcohol, particularly hypertension among men. Our study analyses the effect of different variables on Hypertension. It was 
Table 4

Tests of equality of group means.

\begin{tabular}{llll}
\hline \multirow{2}{*}{ Background Characteristics } & \multicolumn{3}{l}{ Tests of Equality of Group Means } \\
\cline { 2 - 4 } & Wilks' Lambda & F- test & \\
\hline Age & .932 & 7468.81 & .000 \\
Education & 1.000 & 43.82 & .000 \\
Marital Status & .968 & 3348.89 & .000 \\
Occupation & .987 & 1340.68 & .000 \\
Religion & 1.000 & 0.39 & .531 \\
Caste & 1.000 & 17.35 & .000 \\
Wealth quintile & .993 & 723.01 & .000 \\
Place of residence & .998 & 171.04 & .000 \\
States & 1.000 & 11.89 & .001 \\
Smoking & .998 & 188.66 & .000 \\
Alcohol & .993 & 708.34 & .000 \\
Both Tobacco and Alcohol & .996 & 382.81 & .000 \\
Diet & 1.000 & 50.41 & .000 \\
Diabetic & .993 & 722.96 & .000 \\
BMI & .952 & 5105.47 & .000 \\
\hline
\end{tabular}

Sources: Based on author's computation from NFHS-4 (2015-16).

${ }^{a}$ Model was tested at degrees of freedom $(\mathrm{df} 1)=1$ and $\mathrm{df} 2=101736$.

Table 5

Result of discriminant function of men who are suffering with hypertension.

\begin{tabular}{lcccc}
\hline Function & Eigenvalue & $\%$ of Variance & Cumulative $\%$ & $\begin{array}{l}\text { Canonical } \\
\text { correlation }\end{array}$ \\
\hline 1 & $.108^{\mathrm{a}}$ & 100.0 & 100.0 & .312 \\
First function 1 canonical discriminant functions were used in the analysis. \\
Sources: Based on author's computation from NFHS-4 (2015-16).
\end{tabular}

Table 6

Standardized canonical discriminant function coefficients.

\begin{tabular}{ll}
\hline $\begin{array}{ll}\text { Background } \\
\text { Characteristics }\end{array}$ & $\begin{array}{l}\text { Standardized Canonical Discriminant Function } \\
\text { Coefficients }\end{array}$ \\
\cline { 1 - 2 } \cline { 2 - 2 } Age & Function \\
Education & .721 \\
Marital Status & .029 \\
Occupation & -.049 \\
Religion & .033 \\
Caste & .011 \\
Wealth quintile & -.059 \\
Place of residence & .117 \\
States & .022 \\
Smoking & -.023 \\
Alcohol & -.044 \\
Both Tobacco and Alcohol & .098 \\
Diet & .051 \\
Diabetic & .028 \\
BMI & .129 \\
\hline
\end{tabular}

Sources: Based on author's computation from NFHS-4 (2015-16).

observed the lowest share of normotensive people belonged to the age group 40-49. While education did not seem to act as a determinant of high BP, marital status sure was. The least likelihood of hypertension was seen among the never-married individuals after controlling other backgrounds. Several reasons can be attributed to that, responsibilities associated with married life bring along stress which might be one of the pertinent reasons. Professional work was seen to be associated with the greatest chances of raised BP, here again; the role of stress associated with work might be another important reason. Also, as compared to manual labor, professional workers are relatively less active physically contributing to cardiovascular morbidities, like hypertension. ${ }^{23,24}$ In the case of rural-urban comparison, it should be noted that apart from factors like food habits, stress levels and sedentary lifestyles, pollution in urban areas is now coming up as an important determinant of raised BP. ${ }^{15,25,26}$ It is interesting to note that substance use, consumption of
Table 7

Classification results.

\begin{tabular}{|c|c|c|c|c|c|}
\hline & & \multirow[t]{2}{*}{$\begin{array}{l}\text { Prevalence of } \\
\text { hypertension }\end{array}$} & \multicolumn{2}{|c|}{$\begin{array}{l}\text { Predicted } \\
\text { Group } \\
\text { Membership }\end{array}$} & \multirow[t]{2}{*}{ Total } \\
\hline & & & 0 & 1 & \\
\hline \multirow[t]{6}{*}{ Original } & Count & 0 & 83202 & 1346 & 84548 \\
\hline & & 1 & 15874 & 1316 & 17190 \\
\hline & & Ungrouped cases & 1518 & 49 & 1567 \\
\hline & $\%$ & 0 & 98.4 & 1.6 & 100.0 \\
\hline & & 1 & 92.3 & 7.7 & 100.0 \\
\hline & & Ungrouped cases & 96.9 & 3.1 & 100.0 \\
\hline \multirow{4}{*}{$\begin{array}{l}\text { Cross- } \\
\text { validated }^{\mathrm{a}}\end{array}$} & Count & 0 & 83194 & 1354 & 84548 \\
\hline & & 1 & 15878 & 1311 & 17190 \\
\hline & $\%$ & 0 & 98.4 & 1.6 & 100.0 \\
\hline & & 1 & 92.4 & 7.6 & 100.0 \\
\hline
\end{tabular}

Sources: Based on author's computation from NFHS-4 (2015-16).

a $83.1 \%$ of cross-validated grouped cases correctly classified.

alcohol and tobacco alone, or together, was found to be a very crucial determinant of elevation in BP. The prevalence of hypertension was higher amongst tobacco users as compared to the general population. These findings are in agreement with previous studies where tobacco was found to be a contributing factor for hypertension due to various reasons ranging from oxidative stress, catecholamine release, and endothelial dysfunction. ${ }^{14,15}$ Furthermore, it can be seen that a higher percentage of tobacco users were hypertensive as compared to either solely alcohol users or both. This might be because of the cardio-protective effect of light to moderate alcohol consumption as revealed by many studies. ${ }^{27,28}$ However, people with addiction to substances like tobacco and alcohol, either alone or in combination, have a higher proportion of mildly high BP than the rest of the subjects. ${ }^{29}$ It should be noted that both smoking and use of smokeless tobacco have been found to contribute to the rise in $\mathrm{BP}$, the latter being more critical in a country like India. India is the second-largest consumer of tobacco, one in every three Indians is a tobacco user, contributing to around $18 \%$ of the global share of tobacco users. ${ }^{30,31}$ This huge burden of tobacco use poses a threat to the possible emergence of hypertension amongst the younger individuals in the country. ${ }^{15,31}$ It calls for stricter laws against the sale and purchase of tobacco, especially to adolescents. Our study further finds that alcohol consumption is also an important determinant of hypertension among Indian men aged 15-54. This finding is supported by previous studies that stated the ill effects of alcohol on blood pressure. ${ }^{13,32}$ The reasons can be various, the build-up of xenobiotics due to liver dysfunction and the toxic effects of alcohol metabolites (like aldehyde), cardiovascular dysfunction, and dyslipidemia. ${ }^{1}$ Furthermore, the current use of both alcohol and tobacco was also suggestive of elevated risk for hypertension. Based on these findings, this study suggests the expansion of intervention programs for reducing consumption of tobacco and alcohol in India and calls for regular screening of alcohol and tobacco users for hypertension. These regulatory measures are earnestly required keeping in view that more and more studies are revealing that alcohol, even in minor quantities, has a profound negative impact on the body. ${ }^{29}$

\section{Conclusion}

In conclusion, many factors affect the occurrence of hypertension, many of which are non-modifiable, such as age and gender. However, amongst the modifiable risk factors, alcohol and tobacco use are found as crucial determinants of hypertension in Indian men. Hypertension is a chronic disease and is itself a causative factor for several other diseases like renal impairment, other cardiovascular diseases, and stroke. Checking on abuse of these substances can potentially reduce the disease and health expenditure burden on treatment and care of diseases associated with hypertension in a country like India. Therefore, to improve 


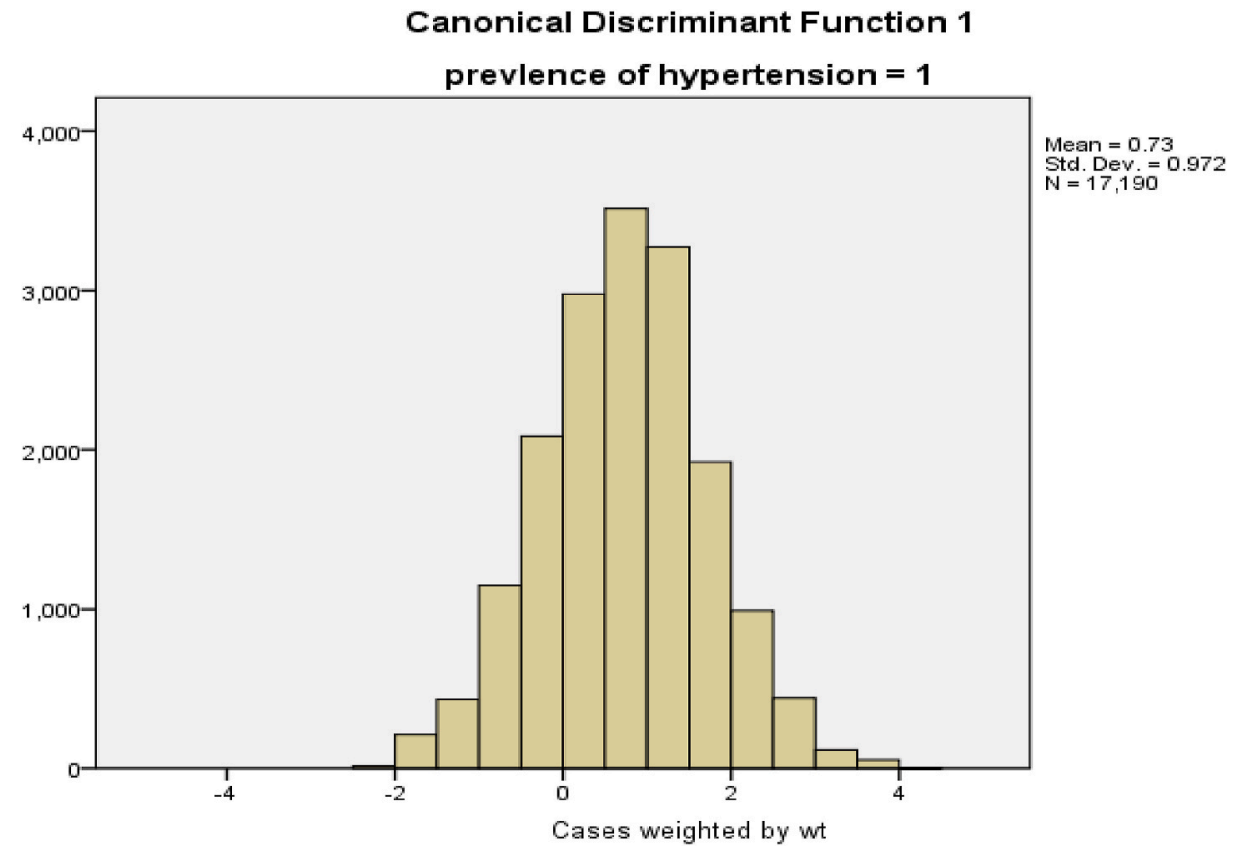

Fig. 1. Histograms showing the distribution of discriminant scores for hypertension.

the general well-being and thus the productivity of the country as a whole, policies to check the abuse of these two substances are much needed and updated in India.

\section{Ethics statement}

The present study used the data from secondary sources which is freely available to individuals. Therefore, no ethical approval is required separately for the present study.

\section{Funding}

No funding was received to conduct this study.

\section{Ethical approval}

Not required.

\section{Author contributions}

JY, CS and SA conceived the idea for the study and developed the analysis plan. JY contributed to the data analysis. SA, CS GJ and JY wrote the initial draft and all authors were involved in commenting on subsequent revisions.

\section{Declaration of competing interest}

None declared.

\section{References}

1 Fauci AS, Kasper DL, Hauser SL, Jameson JL, Loscalzo J. In: Longo DL, ed. Harrison's Principles of Internal Medicine. twentieth ed. New York: Mcgraw-hill; 2018.

2 Whelton PK, Carey RM, Aronow WS, et al. Guideline for the prevention, detection, evaluation, and management of high blood pressure in adults: a report of the American College of Cardiology/American Heart Association Task Force on Clinical Practice Guidelines. J Am Coll Cardiol. 2017;71:e127-248, 2018.

3 Bakris G, Sorrentino M. Redefining hypertension-assessing the new blood-pressure guidelines. N Engl J Med. 2018;378:497-499.

4 Puar TH, Mok Y, Debajyoti R, Khoo J, How CH, Ng AK. Secondary hypertension in adults. Singap Med J. 2016;57:228.
5 Olsen MH, Angell SY, Asma S, et al. A call to action and a lifecourse strategy to address the global burden of raised blood pressure on current and future generations: the Lancet Commission on hypertension. Lancet. 2016;388:2665-2712.

6 Ferdinand KC. Substance abuse and hypertension. J Clin Hypertens. 2000:37-40.

7 Park K. Textbook of Preventive and Social Medicine. 24th Edition. Jabalpur Banarsidas publishers; 2017.

8 IIPS I. National Family Health Survey (NFHS-4), 2015-16: India. Mumbai: International Institute for Population Sciences; 2017.

9 Danaei G, Finucane MM, Lin JK, et al. National, regional, and global trends in systolic blood pressure since 1980: systematic analysis of health examination surveys and epidemiological studies with 786 country-years and 5. 4 million participants. Lancet. 2011;377:568-577.

10 Wakabayashi M, McKetin R, Banwell C, et al, Thai Cohort Study Team. Alcohol consumption patterns in Thailand and their relationship with non-communicable disease. BMC Publ Health. 2015;15:1297.

11 Hu N, Zhang Y, Nair S, W Culver B, Ren J. Contribution of ALDH2 polymorphism to alcoholism-associated hypertension. Recent Pat Endocr Metab Immune Drug Discov. 2014;8:180-185.

12 Roerecke M, Tobe SW, Kaczorowski J, et al. Sex-specific associations between alcohol consumption and incidence of hypertension: a systematic review and metaanalysis of cohort studies. Journal of the American Heart Association. 2018;7, e008202.

13 Fernandez-Sola J. Cardiovascular risks and benefits of moderate and heavy alcohol consumption. Nat Rev Cardiol. 2015;12:576.

14 Gupta R, Gupta N, Khedar RS. Smokeless tobacco and cardiovascular disease in low and middle income countries. Indian Heart J. 2013;65(4):369-377.

15 Huntington-Moskos L, Turner-Henson A, Rice M. Tobacco exposure, weight status, and elevated blood pressure in adolescents. J Community Health. 2014;39:653-659.

16 Winniford MD. Smoking and cardiovascular function. J Hypertens Suppl: official journal of the International Society of Hypertension. 1990;8:S17-S23.

17 Thurnham DI. An overview of interactions between micronutrients and of micronutrients with drugs, genes and immune mechanisms. Nutr Res Rev. 2004;17: $211-240$.

18 Roy A, Praveen PA, Amarchand R, et al. Changes in hypertension prevalence, awareness, treatment and control rates over 20 years in National Capital Region of India: results from a repeat cross-sectional study. BMJ open. 2017;7, e015639.

19 Lehmann N, Möhlenkamp S, Mahabadi AA, et al. Effect of smoking and other traditional risk factors on the onset of coronary artery calcification: results of the Heinz Nixdorf recall study. Atherosclerosis. 2014;232:339-345.

20 Phan TP, Alkema L, Tai ES, et al, Forecasting the burden of type 2 diabetes in Singapore using a demographic epidemiological model of Singapore. BMJ Open Diabetes Research and Care. 2014;2, e000012.

21 Stang J, Story MT, eds. Guidelines for Adolescent Nutrition Services. Center for Leadership, Education and Training in Maternal and Child Nutrition; 2005:93.

22 Dixit S, Ansari MA, Khan Z, Khalique N. Prevalence and predictors of tobacco use; a cross-sectional household survey in Aligarh District of Uttar Pradesh. Indian J Community Health. 2012;24:203-208.

23 Mustacchi P. Dr mustacchi responds. West J Med. 1990 Dec;153(6):664.

24 Thayer JF, Yamamoto SS, Brosschot JF. The relationship of autonomic imbalance, heart rate variability and cardiovascular disease risk factors. Int J Cardiol. 2010;141: $122-131$. 
25 Sørensen M, Hoffmann B, Hvidberg M, et al. Long-term exposure to traffic-related air pollution associated with blood pressure and self-reported hypertension in a Danish cohort. Environ Health Perspect. 2012;120:418-424.

26 Sun Q, Yue P, Ying Z, et al. Air pollution exposure potentiates hypertension through reactive oxygen species-mediated activation of Rho/ROCK. Arterioscler Thromb Vasc Biol. 2008;28:1760-1766.

27 Lakshman R, Garige M, Gong M, Leckey L, Varatharajalu R, Zakhari S. Is alcohol beneficial or harmful for cardioprotection? Genes \& nutrition. 2010:111-120.

28 Rodríguez-Morató J, Boronat A, Dierssen M, de la Torre R. Neuroprotective properties of wine: implications for the prevention of cognitive impairment. In Role of the Mediterranean Diet in the Brain and Neurodegenerative Diseases. 2018:271-284.
29 Burton R, Sheron N. No level of alcohol consumption improves health. Lancet. 2018; 392:987-988.

30 World Health Organization. Diet, Nutrition, and the Prevention of Chronic Diseases: Report of a Joint WHO/FAO Expert Consultation. World Health Organization; 2003.

31 World Health Organization. South-East Asia Regional Response Plan for Integration of TB and Tobacco. 2017-2021.

32 Olack B, Wabwire-Mangen F, Smeeth L, Montgomery JM, Kiwanuka N, Breiman RF. Risk factors of hypertension among adults aged 35-64 years living in an urban slum Nairobi, Kenya. BMC Publ Health. 2015;15:1251. 